\title{
The assessment of Kurkgöz Bridge in the context of sustainable, cultural and architectural heritage
}

\author{
Z. Akdemir \& G. Sener \\ Faculty of Architecture, Yildiz Technical University, Turkey
}

\begin{abstract}
This study includes the examination of Kirkgöz Bridge, a public structure that is an important part of cultural and architectural heritage and that lost its function as it is out of the transportation networks.

The issue that requires this observation is the alteration of the watercourse of the bridge, which is located on Akarçay Stream adjacent to the city of Bolvadin (Polybotum) on the western part of Anatolia and on the historical King Road. Since it was removed from the transportation networks about a century ago, the bridge has been in danger of being destroyed. In addition to that, the bridge may lose its identity because of the inappropriate interventions of the institution (Head Office of Highways) that undertakes its protection, maintenance and responsibility.

The purpose of this examination is to determine the properties of Krrkgöz Bridge, which includes highly important information about history. For that purpose, documentary information, which includes historical events that have happened near and over the bridge, many interventions that the bridge went through and all other factors that shaped its form and structure will be presented to the architectural environment in a chronological way, and suggestions for its reevaluation in the context of sustainable architectural heritage will be offered.

As a cultural property that should be protected, the concept of 'architectural heritage' is often used instead of immobile cultural entity. Architectural heritage is regarded as an economical asset for the utilization of the resources by the European Council. They state that this heritage is an expression of history and the richness of cultural differences, a guide for a harmonic communal balance and to assist communal integration. As well as providing a variety of material for presentation and comparison of different forms, it also carries a huge potential to
\end{abstract}


trigger a judgmental verdict in education through sustaining and ensuring the remains of different eras. It is clear that architectural heritage contains spiritual, cultural, communal and economical values and its surroundings sustain a harmonious environment that is indispensable for a perfect life. This project will present Kirkgöz Bridge's sustainable architectural inheritance in comparison with Bolvadin in order to understand its full potential.

The methodology that will be applied in this study consists of onsite observation, analysis of spatial and non-spatial factors and evaluation of the potential of the existing environment.

Keywords: sustainability, architectural heritage, cultural heritage, historical bridge.

\section{Introduction}

Anatolia has witnessed the flow of different human populations throughout its history and as a result, its cultural life and, in particular, architecture show the impacts of different cultures. Trade roads, which also constitute a bridge between the different cultures of the East and West, also pass through this geographical region. Anatolia maintained relationships between different cultures, but also reproduced its own specific cultures [1].

Anatolia, in other words Asia Minor, accommodates significant buildings in terms of transportation, accommodation and commerce. Bridges, roads, hans (inns) and caravansaries are among them.

Bridges are the main elements of transportation systems in a terrain such as Anatolia, whereby hills, rivers and passages are abundant. As a result of the surveying studies conducted in 2008, 1376 historical bridges are registered (by the General Directory of National Motorways, Department of Historical Bridges [2]). The main material of almost all of the bridges that have strategic significance is stone. Stone is one of the most important factors in transmission of all these characteristics beyond time. Stone represents the durable and not the temporal. It travels through time and it witnesses time. Stone has been the symbol of endurance and strength during the Roman, Seljuk and Ottoman eras.

It is possible to come across bridges dating back to Hittites as a result of archaeological excavations conducted in Anatolia (Figures 1 and 2).

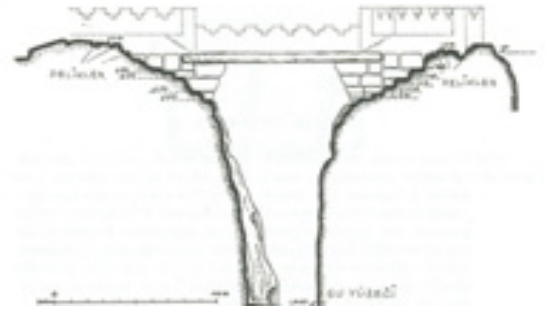

Figure 1: Boğazköy - section.

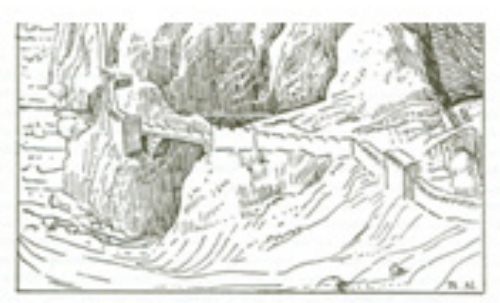

Figure 2: Boğazköy - perspective. 
Kurkgöz Bridge, which can be dated back to 13 th century BC, is built with the stone masonry technique [3].

Moreover, many Roman bridges are still used today either as they are or with renovations or additions. However, whether every culture that has infiltrated Anatolia are affected by each other, or have used the same stone masonry system, they have created genuine products with both the way of using the material as well as the formal properties of the material. For instance, Roman bridges in Anatolia, like those in Europe, have the same semi-circular geometrical formation. These formations, which continued in the Byzantium era, are the other salient characteristics of Seljuk and Ottoman bridges, since the era of Artukoglu mini-state, distinguishing them from Roman bridges [4].

The period in which the bridge construction technology was developed had been the centuries of expansion of the Roman Empire in the Mediterranean Basin. The existence of a significant number of bridges constructed in that period in Anatolia, in other words Asia Minor, which was a highly important region for the Roman Empire, is known [5].

The roads are strategic aspects from the viewpoint of States. That the Roman Empire had established a developed system of roads and transportation had a profound impact on the fact that she could retain her existence for such a long time [6]. The most significant document regarding the road network of the Roman Empire is the Peutinger Map, dating back to $3^{\text {rd }}$ century BC. The section of that map illustrating Asia Minor displays how developed the military road network was in that region [7] (Figure 3).

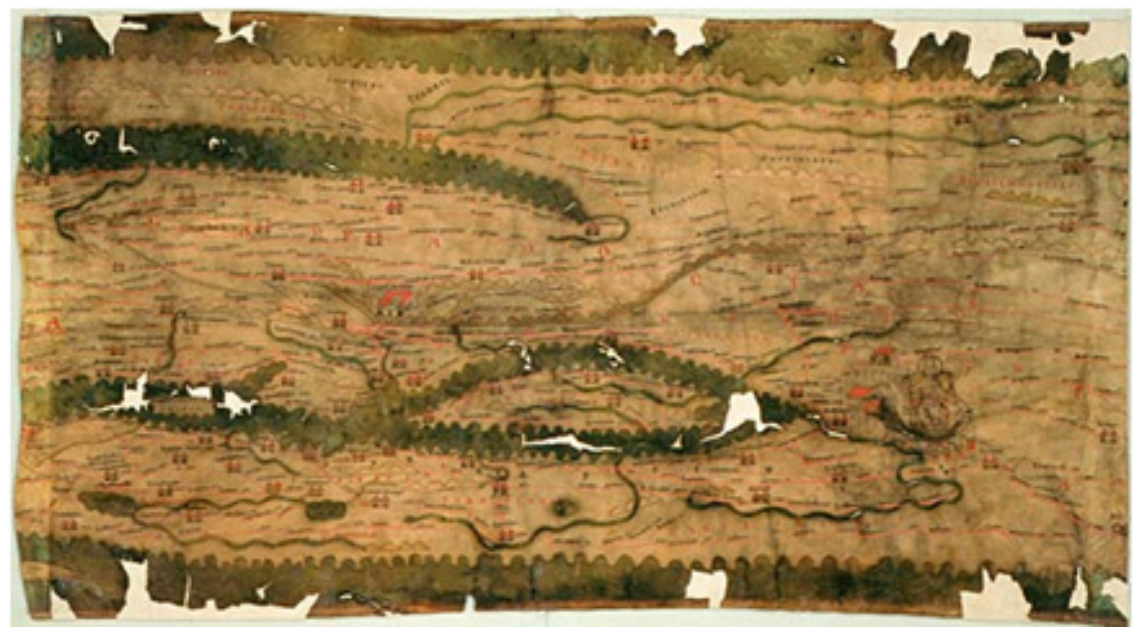

Figure 3: Tabula Peutingeriana, sheet IX. On the left-hand side Russia (above) and the Black Sea, the eastern part of Asia Minor, the narrow Mediterranean Sea with the island of Cyprus, and on the bottom the Levantine coast and the Holy Land. On the right-hand side Russia, Syria and the eastern parts of Turkey with the remarkable representation of Antioch. 
Bridge architecture in Anatolia consists of two main types.

1. Steep Bridges with strong ascents from both sides towards the large and high main central arch (Seljuk and Ottoman periods).

2. Flat Bridges with no major difference between two or more arches in terms of height and width [8].

Kırkgöz Bridge carries the characteristics of the second type (Figure 4).

One of the bridges that have significance in the transportation system of Anatolian Geography is the Kirkgöz Bridge, which is located in the southeast of the Bolvadin (Polybotum) district of the city of Afyon. Bolvadin is located on the inner-western part of Anatolia on the north of Lake Eber, and is surrounded by the Sultan Mountains, Emir Mountains and Pasha Mountains. Kırkgöz Bridge lost its function in time mainly due to the change in the direction of the Akarcay (River Kaystos), whereby it gradually became isolated from the transportation network (Figure 5).

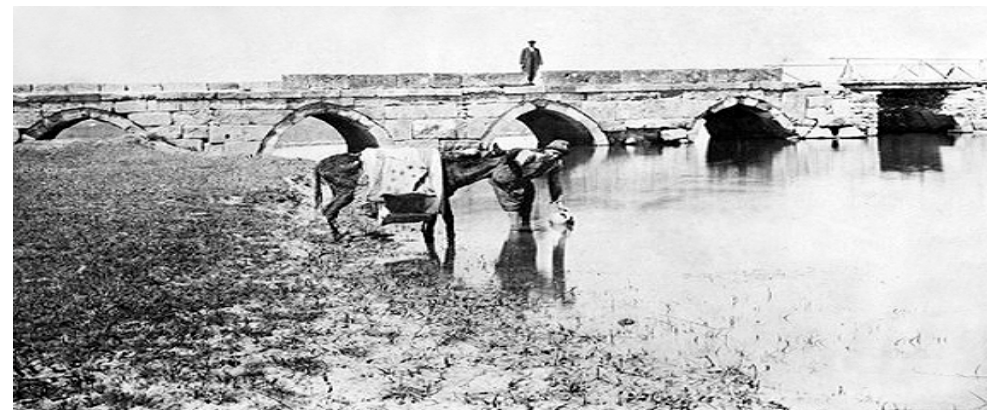

Figure 4: Kirkgöz Bridge - 1960s.

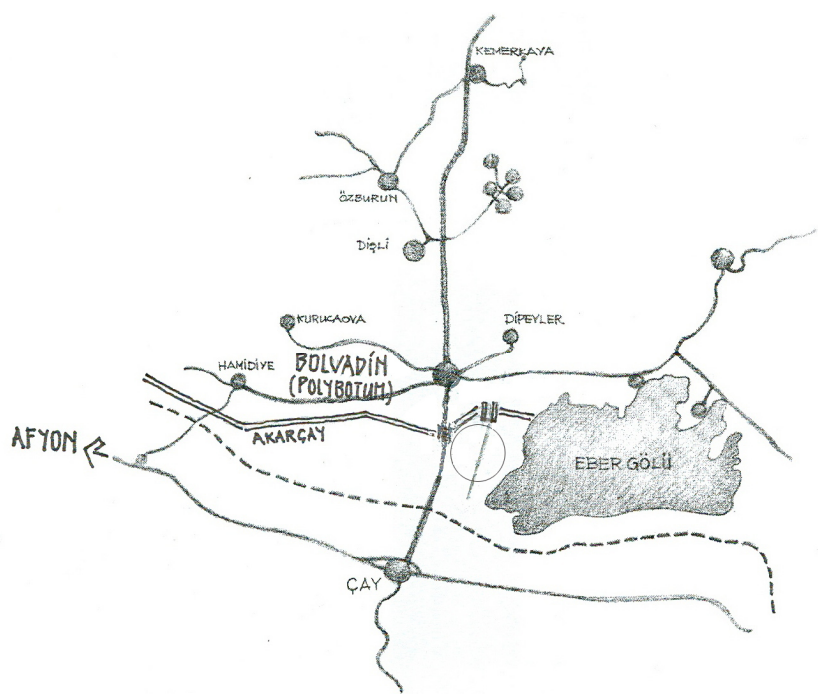

Figure 5: $\quad$ Location map. 


\section{Kırkgöz Bridge}

Kırkgöz Bridge is named after the word "kirk", which expresses the notion of multiplicity in Turkish Mythology. The bridge is positioned over the Akarçay (River Kaystros) that pours into Eber Lake, which is located $7 \mathrm{~km}$ south of the Bolvadin (Polybotum) district along the Anatolian Caravan Road. Historical King's Way, which is mentioned in many military and commercial journeys, also passes along this bridge.

Silk Road, which starts from China, passing Middle Asia and reaching Anatolia over Persia, also passes along Kırkgöz Bridge.

Historical Kings Way starts from Hattusa, the capital of Hittites, and passes through Castle Gavur near the capital Ankara. It enters the border of Afyon from Spalya (Sivrihisar) and the border of Polybotum (Bolvadin) bay, passing through Yedikapi from Avrra (Amorium-Hisarköy). It passes from Kayster Pedion (Üç Höyükler) and Kırkgöz Bridge. It used to reach Ephesus, which once was a port city, by passing through the city of Apamie (Dinar) via Valma (Karamıkkaracaviran) [9].

Although it has not been possible to reach definite findings regarding the exact date of its construction, the first sources that mention this bridge are the Hitite tablets in Ankara ProAsia Civilizations Museum.

This bridge has witnessed a number of crusades, wars, processions, destructions, restorations, additions and interventions, as well as the passage of significant historical figures. Some of these events are chronologically listed below (Figure 6).

- 1344 BC. Hittite King Mursil the $\mathrm{II}^{\mathrm{nd}}$ used this bridge for the Arzava Crusade (written in Hitite tablets in Ankara ProAsia Civilizations Museum).

- 401 BC. It is written that Cyros, Anatolian governor of Persia, has passed this bridge with his armies of more than tens of thousands of soldiers.

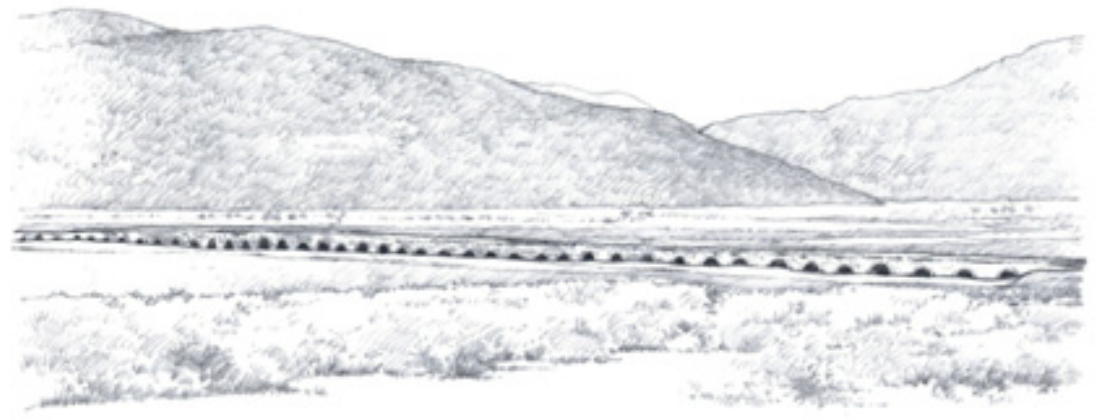

Figure 6: Kırkgöz Bridge. 
- 301 BC. Ipsos War occurred between Antigone and other generals of Alexander the Great.

- 133 AD. The Roman Emperor Hadrianus drops by Polybotum (Bolvadin) during his visit to Anatolia. A coin was introduced to commemorate this visit and his sculptures are erected all over the city. He improves the bridge alongside the city of Bolvadin.

- 1070. Byzantium King Romulus Dyogene repaired the bridge, along with the roads.

- 1097. Crusaders fought over this bridge and damaged it.

- 1150. Manuel Comnena, Byzantium Emperor, repaired the bridge.

- 1107. Seljuk Sultan Kilicarslan the $1^{\text {st }}$ takes Bolvadin into Turkish territory.

- 1362. Ottoman Emperor Murat the $1^{\text {st }}$ takes Bolvadin into Ottoman territory. Ottoman emperors used Kirkgöz Bridge in all their Eastern crusades. Sultan Bayazid, Sultan Murat the $2^{\text {nd }}$, Sultan Mehmet the Conqueror in the Karaman War, Sultan Yavuz Selim in the Caldiran War, Solaiman the Magnificent in the Persian War and Sultan Murat the 4th in the Baghdat War used this bridge.

- 1534. Solaiman the Magnificent conquered Baghdat by passing from this bridge. Before the Revan Crusade he maintained the roads. He sent Architect Sinan to Bolvadin in 1550 to repair this bridge. The number of arches was increased up to 64 and a prayer area was added to the Bolvadin side.

- 1895. Roads changed after the opening of the Berlin-Baghdat Railway. The Sogutlu Road, which connected Bolvadin to Kurkgöz, lost its significance. The New Station Road was opened and Develi Bridge was widened. Kırkgöz Bridge lost its function. It was abandoned after 1970 [10].

Kirkgöz Bridge was used in periods starting from the Eastern Roman Empire, the Byzantine, up to the Seljuk and Ottoman Empires. The road is currently outside the main route, and it is near the road between Çay and Bolvadin.

The bridge is composed of three separate sections that have been constructed in different historical periods. It is indicated that the bridge previously had 64 eyes but today it has a total of 56 eyes. Eight of the bridge eyes were demolished by the State Hydraulic Works in the Republican period, during the formation of the new Akarçay river course towards the north of the existing course.

The oldest part of the bridge is the one from the Roman period and is located on the Akarçay river course. This section starts from the $23^{\text {rd }}$ arched opening from the east. This section, which has in total 15 round arches, ends at the $37^{\text {th }}$ arch opening on the east. The distances of arch openings and wall construction techniques change at this section. The arches are made of large basalt stones and they have circular forms. This type of arched bridge is observed in the early stages of the Roman Empire period (Figure 7). 

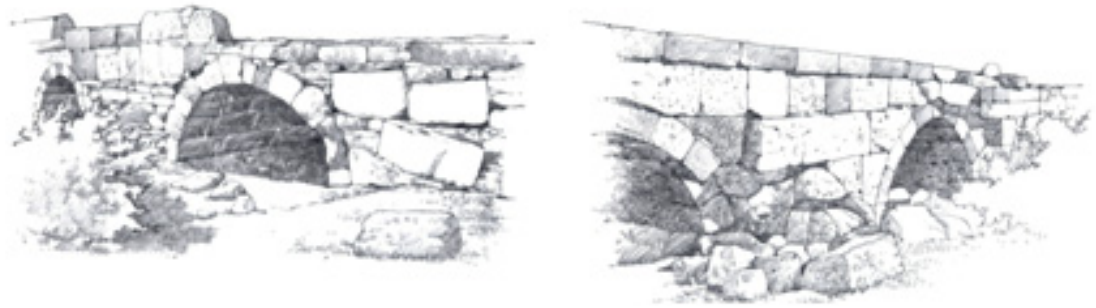

Figure 7: Roman period.

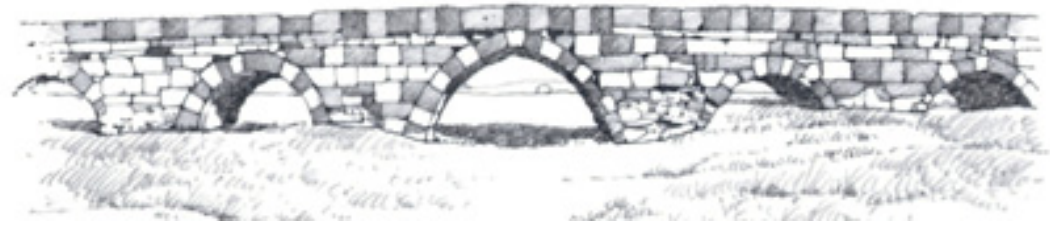

Figure 8: $\quad$ Sketch of Kırkgöz Bridge - Seljuk period.

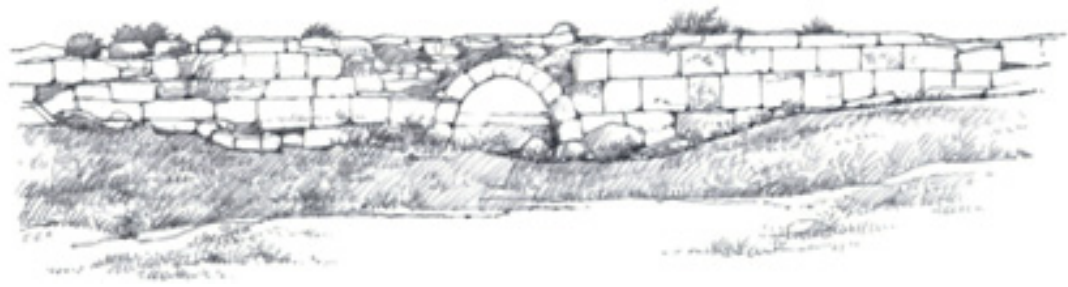

Figure 9: $\quad$ Sketch of Kirkgöz Bridge.

The west part of the bridge that starts from $38^{\text {th }}$ arched opening has 19 arches and is from the Seljuk period. The arched openings have different sizes. Usually double-centered pointed tangent arches are used. The span of the arches increases and rises towards the middle section of the bridge. The $41^{\text {st }}$ arch from the east is the highest and the most extensive arched opening at this section [11] (Figures 8 and 9)

What survives to the south of the old bridge shows that originally the road was on the low ground and that later the annual flooding of Lake Eber raised the bed of the marsh and made the construction of the embankment imperative [12].

\section{Sustainability of cultural and architectural heritage}

The definition of the Sustainable City: "In order to ensure continuity and change, the cities are aligned with the socio-economic concerns related to environmental and energy concerns, these three dimensions are put forward by a coordinated approach. Sustainability of cities requires giving the necessary importance to the natural and cultural environment. Environment; directly contributes to the 
quality of human life, also increase the tendency towards the idea of peace and security in general, the transmission of the heritage from the past to the future" [13].

The approach which advocated that the balance between environment and development would be provided via urban transformation was dominating the discourse when the report of "Our Common Future" by the United Nations Council of Environment and Development in 1987 was defined. In the report, sustainable development is described as "meeting today's needs without compromising the possibility of future generations providing their own needs". According to the report:

-The process of destruction of both the ecosystem and diversity of species must be stopped.

-Technologies that do not damage natural resources and the environment should be developed [14].

-The relevant articles by the Council of Europe about the protection of the architectural heritage are as follows:

Article 1: Apart from its priceless cultural value, Europe's architectural heritage gives to her peoples the consciousness of their common history and common future. Its preservation is, therefore, a matter of vital importance.

Article 2: The architectural heritage includes not only individual buildings of exceptional quality and their surroundings, but also all areas of towns or villages of historic or cultural interest.

Article 4: Architectural conservation must be considered, not as a marginal issue, but as a major objective of town and country planning [15].

-The relevant articles from the Venice Charter (May 1964) about the protection of the Cultural and Architectural Heritage are as follows:

Article 9: The process of restoration is a highly specialized operation. Its aim is to preserve and reveal the aesthetic and historic value of the monument and is based on respect for original material and authentic documents. It must stop at the point where conjecture begins, and in this case moreover any extra work which is indispensable must be distinct from the architectural composition and must bear a contemporary stamp. The restoration in any case must be preceded and followed by an archaeological and historical study of the monument.

Article 11: The valid contributions of all periods to the building of a monument must be respected, since unity of style is not the aim of a restoration. When a building includes the superimposed work of different periods, the revealing of the underlying state can only be justified in exceptional circumstances and when what is removed is of little interest and the material which is brought to light is of great historical, archaeological or aesthetic value, and its state of preservation good enough to justify the action. Evaluation of the 
importance of the elements involved and the decision as to what may be destroyed cannot rest solely on the individual in charge of the work.

Article 12: Replacements of missing parts must integrate harmoniously with the whole, but at the same time must be distinguishable from the original so that restoration does not falsify the artistic or historic evidence [16].

\section{Sustainability of Kırkgöz Bridge as a cultural and architectural heritage}

What is a World Heritage bridge? The World Heritage Committee states that to be of World Heritage status a monument or site must be of outstanding universal value. It must illustrate or interpret the heritage of the world in terms of engineering, technology, transportation, communication, industry, history or culture. World Heritage industrial sites and monuments must meet one or more of the following criteria and pass the test of authenticity.

- Represent a masterpiece of human creative genius.

- Have exerted great influence, over a span of time or within a cultural area of the world, on developments in engineering theory, technology, construction, transportation and communication

- Be an outstanding example of a type that illustrates a significant stage in bridge engineering or technological developments [17].

One of the most significant criteria of the development of societies is the preservation and transmission of cultural and architectural heritage for the future.

Historical bridges are significant structures showing the social-culturaleconomic level of the era in which they are constructed. They are significant witnesses of history [18].

Preservation is a multi-dimensional concept. It requires a multidisciplinary work. Preservation can only be achieved when considered in accordance with "development", "assessment" and "refunctioning". It is highly likely to be confronted with serious problems, despite the existence of a legal and institutional framework regarding the matter of the preservation of rich heritage in the Anatolian Geography [19] (Figure 10).

According to the report published at the end of 2008 by the institution responsible for historical bridges (the General Directory of National Motorways, Department of Historical Bridges), 1376 historical bridges are registered. This unit, which was established in 2003, has realized the restoration and repair of an increasing number of bridges every year.

The projects for the restoration of these bridges have to be approved by the Preservation Councils of the relevant region. Stages of survey, documentation and project are overcome by relatively less problems as they require comprehensive studies. However, the implementation of these projects is usually performed by contractors that are insufficient in terms of required expertise. 


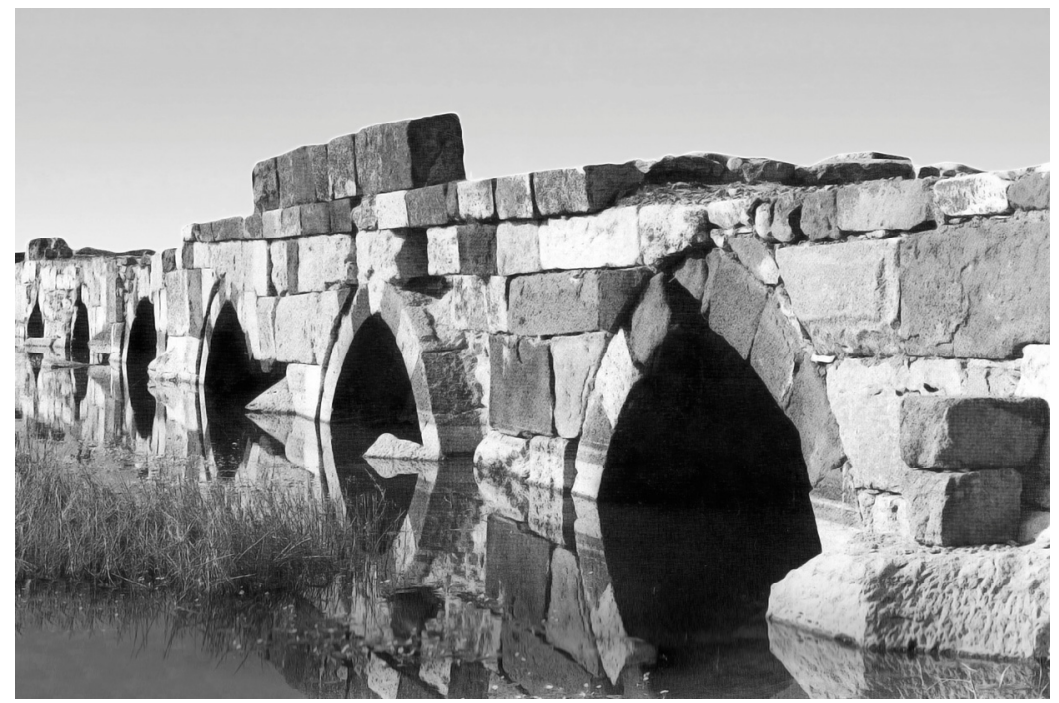

Figure 10: Seljuk period.
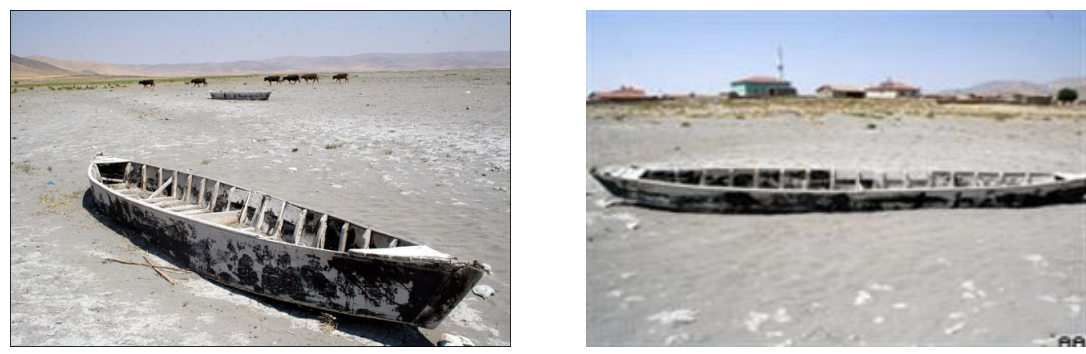

Figure 11: Lake Eber today.

These structures are faced with irreversible interventions because of the ineffectiveness of the mechanisms of control. They are faced with the risk of losing the additions acquired in time as the witnesses of different historical eras.

Kırkgöz Bridge has managed to retain its original identity with its additions acquired through time until 2003. It is known that buildings that no longer have a function face an even more rapid dilapidation process. These structures are the common heritage of humanity, and the responsibility of their transmission to the future is well indicated in the legal articles of both the Venice Charter of 1964 and the EU Amsterdam Declaration of 1975.

Another important problem is the pollution of natural water sources of the city, such as Lake Eber and Heybeli Thermal Waters, because of industrial wastes. Lake Eber, which is an important economic potential for the city, has been losing its natural habitat. Heybeli Thermal Waters is also important as a potential health tourism center. For now, these two water resources cannot be used efficiently (Figures 11 and 12). 

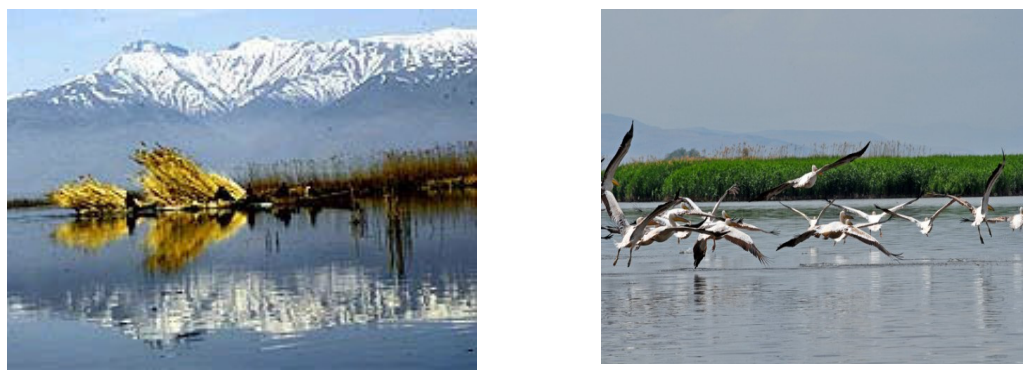

Figure 12: $\quad$ Lake Eber in 2000.

One other problem is that, regardless of the cultural and social heritage of the different civilizations that shaped the center of the city, the new developments grow in a system that does not consider the organic pattern of the historic center. Thus, the city center keeps losing its characteristic spatial properties [20].

Kırkgöz Bridge and other bridges with similar characteristics (isolated from the transportation connections) can be preserved and transmitted to the future by interventions that will not damage the genuine identity in accordance with the potentials provided by the region, area and the city. Re-functioning of bridges is quite limited when compared to other architectural heritage.

\section{Conclusion}

Bridges are important components of the transportation system in terms of their main functions. Some of the historic bridges in the geography of Anatolia retain their presence in vehicle and pedestrian transportation. However, it is very difficult for their presence to continue, particularly in places within or around rural settlements, or for bridges that no longer have a function away from the transportation connections. The required intervention, in the discipline of protection, is conservation rather than restoration. Kırkgöz Bridge can trigger sustainable development in its vicinity due to its historical value, and it can be an attraction point, at national or international scale, as an archaeological park on which historical routes intersect. A cultural route, including nearby antique towns that can enable daytrips, has the potential of economic, social and cultural development in the region.

The bridge, which is located in the catchment basin of Eber Lake, has the potential to affect the region by its historical value. Eber Lake is extremely valuable in terms of ecosystem. It is located on the migration routes of birds. It hosts important bird species. It is rich with biological diversity. The economic life of rural settlements depends on the lake. Reeds and fishing are of important economic value.

The shutting down of the paper factory, which was established by the State several years ago, in the 1990s, has affected the region's socio-economic life. The pollution carried by rivers flowing into the lake and the drought experienced 
in recent years caused serious pollution and drought in Lake Eber. The region was confronted with an environmental disaster in terms of ecosystem. Local efforts are insufficient against the central government's wrong policies about the natural environment. The introduction of the problems in different scales and the development of solutions may create pressure on the central government and related institutions. The attention of academia or civil society organizations at national and international scale, which are the 21 st century's major dynamics, may focus on the region's socio-economic and environmental problems. Civil dynamics may create an agenda and may lead to opening different solution channels by involving people in the process who lives in the area. Kirkgöz Bridge can move the social-environmental-economic problems to the public, which have become the common problems of humankind, over its own historical and memorial value.

\section{References}

[1] Ceylan, O., Gökçen, T., Çağlar Boyu Göç ve Ticaret Yollarının Kesiştiği Anadolu'da İnsan Hareketlerini Malzeme ve Mimari İlişkilerine Etkileri, "Anadolu'da Malzeme ve Mimarlık Sempozyumu ", İstanbul, 4-5 Temmuz 2005

[2] Karayolları Genel Müdürlüğü, Köprüler Dairesi Başkanlığg,Tarihi Köprüler Şubesi Müdürlüğü http://www.kgm.gov.tr

[3] Nauman, R., "Eski Anadolu Mimarlığı", Türk Tarih Kurumu, Yayınları, IV. Dizi-Sa. 9b, s. 492-493, Ankara, 1991

[4] Eyüce, Ö., "Köprüler", İzmir İleri teknoloji Enstitüsü Rektörlüğü Yayını, Basım No:IYYE2, s.38, İzmir, Haziran/1988

[5] Binan, C., "Anadolu'da Ulaşım ve Konaklama Yapıları Bağlamında Mimarlık, Malzeme ve Yapı Üretimi Üzerine Yorumlar", Geçmişten Geleceğe "Anadolu'da Malzeme ve Mimarlık" TMMOB, Mimarlar Odas1 Kongre Kitab1, ISBN9944-89-092-8, Nisan 2006, XXII. Dünya Mimarlık Kongresi UIA İstanbul, 2005

[6] Kretzshmer, F., "Antik Roma'da Mimarlık ve Mühendislik", Arkeoloji Sanat Yayınları, s.116, İstanbul, 2000

[7] Peutınger Haritası http://198.62.75.1/www1/ofm/mad/articles/Weber Peutıngeriana.html

[8] İlter, F., "Osmanlılara Kadar Anadolu Türk Köprüleri", s.27, Karayolları Genel Müdürlüğü Yayınları, Ankara, 1978

[9] Bayar, M., "Anadolu'nun Eski Şehirlerinden Bolvadin'in Tarihi", Cilt1, s.76-77., 1966

[10] Bayar, M., Bolvadin Tarihi, Cilt2, s.322, Bolvadin, 2004

[11] Eravşar, O., Mert, İ.H., "Roma'dan Cumhuriyete Bolvadin Kırkgöz Köprüsü", S.Ü. Sosyal Bilimler Enstitüsü Dergisi, s.75-80, 2003

[12] Harada, L., Cimok,F., "Roads of Ancient Anatolia", Volume Two First Printing, A Turizm Yayıncılık, s.18-21, 2008 
[13] Şahin, İ., "Sürdürülebilir Planlama Girdisi Olarak Kültürel ve Doğal Miras,Uluslar arası Ekolojik Mimarlık ve Planlama Sempozyumu Antalya, 22-25 Ekim 2009

[14] Brundtland Report 2007 http://en.wikipedia.org/wiki/Brundtland Commission

[15] Congress on the European Architectural Heritage, Declaration of Amsterdam, 21-25 October 1975, http://www.icomos.org/docs/ amsterdam.html

[16] Venice Charter, International Charter for the Conservation and Restoration of Monuments and Sites, 1964, http://www.icomos.org/venice_charter.html

[17] Context for World Heritage Bridges http://www.icomos.org/studies/ bridges.htm

[18] Anadolu'nun Kilidi Afyon, T.C. Afyon Valiliği, İl Özel İdareMüdürlüğü, s.173-179, 2004

[19] Akdemir, M.Z., "Batı Karadeniz Bölgesi Yerleşmelerinde Geleneksel Konut Kültürüne Bağlı Biçimsel ve Yapısal Kurgu özelliklerine Ait Ölçütler", Yıldız teknik üniversitesi Fen Bilimleri Enstitüsü, Doktora Tezi, s.2, İstanbul, 1997

[20] Önal, F., Akdemir, Z., Yüksel, Ş., Zeybekoğlu, S., "The City of Bolvadin in Context of Sustainable Urban Environment", XXII.World Congress Of Architecture, İstanbul, UIA, 2005

[21] Lake Eber http://www.yasamkadin.com/v2/resimler/turkiye/23641-1ssizguzellik-eber-golu-burdur.html

[22] Lake Eber http://sultandagi.org

[23] Lake Eber http://www.arsiv.ntvmsnbc.com/news/431006.asp 